\title{
Putting Adam Ferguson in his place ${ }^{1}$
}

\author{
John D. Brewer
}

\begin{abstract}
This paper re-conceptualizes the relationship between Ferguson's life and work by locating him in his biographical and geographical context for the purposes of better understanding his proto-sociological writings. Ferguson's work is relatively unknown outside limited sets of literature and current representations of the link between his life and work risk misplacing him as both Scotsman and sociologist. The popular portrayal suggests there is a strong connection between his Highland background and his famous book An Essay on the History of Civil Society. It will be argued that this claim reproduces the social construction of space in Scottish society and is based on stereotypical views of his birthplace and upbringing. Ferguson did not construct an autobiographical narrative to offer his own understanding of the link between his life and work. This reflects the strengths and weaknesses of sociology as it was developing in the eighteenth century. The 'self' was not recognized as an object of intention or symbolic construction. Ferguson's writings analysed modernity as it was emerging in eighteenth-century Lowland Scotland and contrary to common opinion, there was no self-identity as a Highlander to shape his understanding of that social process.
\end{abstract}

Keywords: Adam Ferguson; civil society; Scotland; self; space

\section{Introduction}

Walking idly through a Scottish graveyard, a philosopher came across the tombstone of Adam Ferguson and subsequently made much of his ignorance of the man (Sorenson 2002). The stroller was clearly not a political philosopher, for Ferguson's work is being celebrated anew for pointing to the limits of liberalism (Hill 1996a, 1997, 1998; Kalyvas and Katznelson 1998). This idea draws on familiar arguments that Ferguson differs from other Scots in recognizing the limits of the market and for establishing an intellectual space between liberalism and republicanism (Benton 1992; Kettler 1965,1977). If our wanderer had been a sociologist he would have known that virtually every 
generation has someone declaring Ferguson as the discipline's founder (Barnes 1917; Benton 1978; Bryson 1939, 1945; Lehmann 1930; MacRae 1969; Swingewood 1970) and luminaries as great as Comte and Marx mentioned him favourably. Our graveyard walker is also oblivious to the modern debate around civil society. With the notable exception of Edwards (2004), most discussions of civil society routinely give obeisance to Ferguson's early exploration of the notion (Dahrendorf 2002; Gellner 1994, 1996; Keane 1988; MacIntyre 1985; Oz-Salzberger 1995; Seligman 2000; Tonkiss 1998). Ferguson's work therefore adds critical insights, as well as historical texture, to several key debates in social theory that should necessitate no blank stare.

This renaissance of interest within limited sets of literature risks the dangers however, that those who come to Ferguson afresh will misplace him and his work as a result his portrayal as a Highlander, developing proto-sociology in order to make sense of his own migration to Lowland Scotland. The purpose of this paper is to reassess the impact of his Highland origins in locating his famous book An Essay on the History of Civil Society (1966[1767]). In representing this book as a Highlander's journey to selfhood, commentators reproduce stereotypical views of social space in Scottish society. These matters are important for two broader reasons. First, placing Ferguson's writings in their proper biographical and geographical context helps newcomers to his work to avoid misunderstanding it. Secondly, the absence of an autobiographical narrative in Ferguson's writings to make his own connection between his life and work reflects some of the strengths and weaknesses of eighteenth-century proto-sociology. The 'self' was un-theorized by these embryonic sociologists; Ferguson's writings analysed modernity as it was emerging in Lowland Scotland and he had no self-identity as a Highlander to affect how he portrayed that social process. In this way, Ferguson was one of the key thinkers who helped make modernity central to the development of sociology as an intellectual project to the neglect, until much later, of issues of self and identity.

It is necessary to begin with a reminder of the sociological perspicuity of Ferguson's writings. This may be familiar to specialists but not a wider audience and is essential for relocating his writings in their proper biographical and geographical context: we need to know Ferguson's writings before we can understand why commentators could reasonably, if erroneously, argue his work merely reproduces his biography.

\section{Ferguson's proto-sociology}

Ironically, the epitaph on Ferguson's tombstone admirably captures the thread through his work when it states that he gave 'steady perseverance in acquiring and diffusing knowledge and in the practice of public and of domestic virtue'. That is, his life's work is cast as the exploration of what modern sociology calls 
the public-private distinction. This antinomy describes the simple idea that individuals exist separate from the state, resulting in a sharp contrast between people's public and private interests. This idea was extended within sociology into a series of binary divisions that contrasted the domestic sphere and broader sources of public identity and activity. The distinction was used to describe the contrast in people's social values between the universal and the particular, the different realms of experience represented by back-stage intimacy and front-stage professional role performance, and the separate normative worlds of the family and work, civil society and the state. Sociology lagged behind political theory in its representation of these as binary divisions, for since Mandeville's Fable of the Bees in 1714 it has been understood that the two penetrate each other, although sociology also now sees it as a blurred binary.

Contemporary sociologists working to deconstruct the public-private dichotomy might have understood this earlier had they encountered those eighteenth-century writers who struggled with the interconnections between commerce and virtue, which is what Mandeville is referring to in his discourse on private vices (economic self-interest, the selfish pursuit of wealth, the desire for betterment and so on) and public benefits (public virtue, collective good). This was such a motif of eighteenth-century thought that Hont and Ignatieff entitle their account of it Wealth and Virtue (1983) and Pocock Virtue, Commerce and History (1985). Ferguson wrestled with their relationship too. In his account of civil society, Ferguson discusses the impact of the public sphere (the social division of labour, private property, wealth and class divisions) on the private sphere (people's sense of alienation, exploitation and the weakening of the social bond), his discussions of which enable commentators to claim he anticipated themes from nineteenth-century sociology (Brewer 1986, 1987, 1989; Hill 1996b, 2001a; Meek 1967; Pascal 1938; Skinner 1982).

Ferguson's Essay is his primary sociological treatise. He develops a typology of societies ('rude', 'barbarous' and 'polished') and contrary to Anthony Brewer's suggestion (1999: 238) that this was a version of the Scots' usual 'law of the four stages', Ferguson adopted a qualitatively different theme based around kinds of social structure. His chief concern however, was to chart the social structure associated with the 'polished' stage, and particularly the threats it faced as a result of its negative features. The pressures were of two sorts. First, commercialism wrought the danger of systemic inequality, manifested in what nineteenth-century sociologists came to describe as alienation, anomie, exploitation, social conflict, class divisions and the social division of labour. In this regard, Ferguson did not believe that commercialism necessarily brought peace, liberty and benevolence. The second threat concerned the risk of tyranny by despots able to manipulate the mob, for which reason Ferguson valued mixed government rather than simplistic versions of democracy. 'The boasted refinements of the polished age', he writes, 'are not divested of danger. 
They open a door, perhaps, to disaster as wide and accessible as any of those they have shut' (Ferguson 1966[1767]: 231). As Hopfl (1978: 37) emphasizes, Ferguson was atypical because he did not celebrate progress (also see Hill 1997). In fact, the final two parts of the Essay are entirely given over to an account of how nations decline.

As John Brewer (1986: 471-5, 1989: 22-3) and Lisa Hill (1996b: 203) have argued, for all his sociological sophistication Ferguson's anticipation of the discipline's core themes was constrained by the civic humanist concerns that provoked his interest in national decline. The central affairs of this tradition are with the political community, defined in institutional terms such as a regular constitution, mixed government and active citizenship. The latter involves people participating in whatever institutional mechanisms of governance exist, such as in the defence of the community (for the example of the Scottish militia, see Robertson 1985; Sher 1989). Active citizenship derives from people's sense of public virtue and civic duty, themes redolent in civic humanism, which Ferguson termed 'civil society'. However, should citizens not fulfil their obligations as a result of the negative effects of polished society, it is no longer a civil society and the political community will be threatened by corruption and decline. Liberty is expressed (and defended) in the exercise of activity not in passivity and leisure. The vocabulary of the civic humanist tradition - virtue, citizenship, corruption, national decline - forms the context to his discussion of private property, the social division of labour, alienation and the like, pulling Ferguson back from developing the discourse of nineteenth-century sociology. His worries about the failure of people to participate in public affairs as they become consumed by private interests, his anxieties over the disintegration of the human personality under the newly developing forms of social relations within commercialism, and his concern about the curtailment of human agency (called then human nature), is animated by the possible loss of virtue and civic spirit in polished society and the potential therein for corruption and decline.

Ferguson's ability to merge civic humanist concerns about duty, virtue and active citizenship with his proto-sociological analysis of social structure gives him extraordinary insight into the viability of civil society. Civil society does require forms of good governance in order to protect personal liberty against the state and the market, but it also requires a particular cultural value system and social structure. This normative system extends well beyond the active citizenship that people universally attribute to Ferguson. The notion of virtue, which was part of the intellectual discourse of antiquity up to the eighteenth century, does not give meaning to these norms, for in many treatments virtue can be seen as describing the type of personal character required for the virtuous person rather than its civic culture. MacIntyre (1985: 195-6) values Ferguson precisely because he locates virtue in a sociological context by giving attention to the normative system underpinning civil society. The cultural 
values that describe this social formation come close to what Putnam means by 'social capital' (as noted by Passey and Tonkiss 2000: 31) because they share norms like trust, duty, benevolence, loyalty, altruism and sociability.

It does not follow that these norms necessarily realize the Epicurean goal of peaceful enjoyment of individual freedom, for they can easily lead to conflict when an out-group threatens the in-group. This realization allowed Ferguson to anticipate nineteenth-century conflict sociology (Hill 2001a) and Durkheim's analysis of social solidarity; and he shared some of Durkheim's fears over the way the social division of labour was changing social bonds. Ferguson argued that the social division of labour negatively impacted on people, particularly in the form of anomie (the alternative notion of alienation is used by Forbes 1966: xxxi and MacRae 1969), thus allowing commentators to draw parallels between Durkheim and Ferguson on anomie (Hill 1996b: 225). However, they shared an essential optimism about the new forms of social solidarity emerging in modernity that counter-balanced its disintegrative effects on the individual, although they conceived the social bond quite differently. Durkheim saw social solidarity being provided by the division of labour itself, in a form he called organic, Ferguson by civil society and its associated normative system.

The second sociological advance Ferguson makes is to begin to map the set of institutional arrangements that define the social structure of civil society. Civil societarians and political theorists are right to stress Ferguson's emphasis on mixed government and voluntary associations as part of the institutional make-up of civil society, a feature owed to his civic humanism, but the 'sociological twist' (a phrased used in Brewer 1986: 473) this tradition takes in his work ensures that the social structure of this kind of social formation is understood more broadly. Its social structure is not based on the traditional segmentary communities of pre-modern times (a point emphasized by Gellner 1994), encapsulated by Tonnies's idea of gemeinschaft, or what Durkheim called mechanic solidarity, with close kinship networks, repressive cultural institutions and an over-bearing cultural hegemony by one group. Commentators get Ferguson wrong when they suggest he laments the passing of this kind of society (for example Hill 1996b: 225; Kettler 1965: 8-9). Dehumanization, over-rationalization, individualization and bureaucratization were risks with the rise of industrialization but not inevitable if the social structure of civil society enacted distributive justice. Mixed government and voluntary associations are part of this: the former avoids the centralization of power in the control of any one group, which protects liberty, and the latter encourages active citizenship, which sponsors benevolence. But the social structure that embeds civil society is more extensive than civil societarians or political theorists paint.

In the Essay Ferguson established the sociological principle that the natural dispositions of people toward each other depend on the form of society they 
find themselves in (1966[1767]: 238). Applying this to civil society he envisaged its social structure as relatively small in scale without extensive territorial enlargement or excessive urbanization. This was not nostalgia for pre-modern village life (suggested by Hill 1996b: 226) but anxiety over large-scale organizations, like conurbations and empires, which risk breaking the social bond by their very size. Anonymity was his target not modernity. The smallness of its scale does not imply any reduction of its complexity, for Ferguson envisaged an institutional framework wherein the education system and social institutions like law, the church and the economic division of labour were organized to create meritocracy and equality of opportunity. Ferguson did not resist the economic division of labour, but required that it be based on meritocratic principles to ensure people ended up in locations to which they were best suited, creating a fairer social division of labour. Ferguson's critique of riches, luxury and conspicuous consumption, and his diatribe against the hereditary principle, which are the flip-side to his concern over the dehumanization of the poor, were animated by his concern that they put people in the wrong places whatever their role - and Ferguson discusses the problems this creates in particular for the army, government and the economic division of labour. In a footnote in the Essay, running over two pages, Ferguson objects to the prioritization of political order in civil society and calls for consideration to be given to what sociologists subsequently called social order.

Our notion of order in civil society is frequently false . . . we think it consistent only with obedience, secrecy, and the silent passing of affairs through the hands of a few. The good order of stones in a wall is their being properly fixed in the places for which they are hewn ... The order of men in society is their being placed where they are properly qualified to act (Ferguson 1966[1767]: 268-9).

He added that political liberty required more than virtue but also 'a distribution of functions in civil society as gives to numbers the exercises and occupations which pertain to their nature' (Ferguson 1966[1767]: 270). The education system played a role in this, as did religion. The latter is perhaps worthy of emphasis to place Ferguson's distinctiveness.

Ferguson kept a strong personal faith and accorded religion special sociological significance (for the comparison with Smith in terms of personal belief see Hill 2001b, for Hume see Force 1984). Ferguson was part of the William Robertson liberal church circle in Edinburgh (Sher 1985); a tradition that a century or so later would permit William Robertson Smith to accommodate himself to a form of evolution theory that saw him ousted from his professorship at Aberdeen (Livingstone 2004). Less important here is the role Ferguson accords deity in the overall design principle of nature (on which see Hill 1998: 54-5); God may be the architect, but also a carpenter, and more significant is the role religion is accorded in building distributive justice into the social 
structure of civil society. Religion helps to shape people's moral senses, it fosters forms of loyalty and identity to the social bond and forms one of a plurality of voluntary associations that help to create cross-cutting cleavages as a bulwark to the consolidation of power in the political despot or traditional segmental community. In the Essay (1966[1767]: 201-2) Ferguson writes of the 'mild spirit of Christianity' - a reference to the vicissitudes between 'old' and 'new light' theology in the Kirk - as helpful in creating the necessary balance between courage and perseverance, gentility and engagement, that are needed in civil society. It is wrong to suggest, as does Sher (1985), that Ferguson's Presbyterianism shapes his analysis of corruption by attributing it to retribution from God; he is not Jeremiah, warning of doom (the analogy used by Sher 1985: 43 and Hill 1997: 686), so much as Elijah, promising deliverance, for corruption can be avoided by maintaining, amongst other things, religion as a central part of the social structure.

In ways such as this, the 'sociological twist' that Ferguson gave his civic humanism is advantageous for understanding his contribution to the debate on civil society. Ferguson grounds civil society in an analysis of the public-private spheres in 'polished' society rather than a narrower attention to forms of governance, in that he addresses the virtuous character needed by people as they engage in active citizenship throughout the private sphere (the domestic sphere and in interpersonal relations), as well as in the public sphere (such as in the voluntary sector, the local community and neighbourhood, the army, the economic division of labour and participatory democracy). But he also recognized that civic virtue needed grounding in a particular cultural value system and social structure. Ferguson articulated this when he wrote that a virtuous character is insufficient without the society to support it (1966[1767]: 270).

\section{Connecting Ferguson's work and life}

The signal contribution of Ferguson's depiction of civil society is that he understood it morally as the good society, requiring a distinctive form of governance and, crucially, a particular cultural value system and social structure, making it a sociological as well as political category. Commentators have speculated on the reasons why Ferguson comes to this remarkably perspicuous view. The conventional approach to understanding Ferguson's work is to locate it in its intellectual antecedents. This has been instructive in connecting Ferguson's work with Roman Stoicism, Italian Renaissance writers, more immediate predecessors like Francis Hutcheson, other Scots and various continental thinkers (on Montesquieu see Mason 1988; for German writers see Oz-Salzberger 1995). We now appreciate that Ferguson marks the transition between intellectual traditions and successfully mediates various sets of discourse - nineteenth-century sociology, civic humanism, political liberalism, and utilitarianism - that initially facilitated his popularity amongst diverse groups. 
Another placement of Ferguson's ideas is in their social context. This context is spatial in referring to a specific time and place - eighteenth-century Scotland - but also cultural, in that particular Scottish values and beliefs affected his work, like Scotland's emphasis on universal and non-elitist education (Bullough 1970; Bullough and Bullough 1971; Morrell 1970), Presbyterianism (Sher 1989), and respect for science, invention and rational enquiry (Christie 1974; Shapin 1974). Scottish social and economic change also helped to shape Ferguson's intellectual agenda, notably the development of an urban and commercial society that successfully integrated people in commerce and trade with the universities (see Emerson 1973a). For example, the coffee houses, clubs and societies that Ferguson frequented and to which he belonged provided a network of contacts that mediated these influences (on the Select Society of Edinburgh see Emerson 1973b; on the University of Edinburgh see Morrell 1970; Sher 1989). Whilst it is therefore possible to accuse Ferguson of having a provincial identity (Kugler 1996), his position in the midst of profound social change was none the less beneficial to his embryonic sociological writings, as Brewer (1989:24-6) has shown with respect to the social division of labour.

However, some commentators locate him as a Highland Scotsman whose proto-sociology bears the footfall of his Gaelic origins (Allan 2006: 5, 151; Forbes 1966: xxxviii-xxix; Forbes 1967: 41; Hill 2001a: 282; MacRae 1969: 19); this is the main conclusion of the latest exposition of Ferguson's life and work (Allan 2006:151). It is easy to understand why. There is nothing in the Essay to suggest his Highland origins but in coming to live and work in Lowland Scotland Ferguson seems himself to be on a transition from 'rude' to 'polished' society, intimately knowing the features of honour, community and the social bonds associated with traditional segmentary cultures, as well as the tyrannies surrounding the cultural hegemony of the clan. He would have been practised in the martial virtues and conflicts of Highlander ways, able to see therefore the positive social functions of conflict, and was avowedly aware from his own life that 'progress' did not necessarily create a civil society. The clash between his Highland origins and Lowland residency must have given him deeply felt experiences of the strengths and weaknesses of both traditional segmentary communities and commercial society that framed his analysis of civil society and its risks. The contrast between these cultural spaces may well have given meaning to his depiction of the normative system and social structure needed to bolster civil society. His sympathy toward small-scale social structures can reasonably be located in terms of the clash between the Highlands and relatively urbanized and cosmopolitan Edinburgh. What came with the Highlands was also a respect for social solidarity and religion's role therein, something reinforced both by his father's Ministry in the Presbyterian church and Ferguson's own nine year chaplaincy in the Highland Black Watch Regiment, all of which gave Ferguson personal acquaintance with civic duty, active 
citizenship, loyalty, communal identity, sociability and strong social bonds. He may well have been attracted to civic humanism as a system to moderate the strains of commercialism because its practise appeared part of his Highland upbringing.

The Highlands however, are as much an imagined as a real social space and these commentators reproduce the symbolic construction of space in Scottish society in connecting Ferguson's life and work in this way. Logierait, Ferguson's birthplace in 1723, is not in the Highlands but border country on the edge of the Grampian Mountains, set in the Tay Valley on a direct travel route to Perth, the county town about twenty miles south; Edinburgh is 43 miles and Glasgow 59 from Perth. Modernity has compressed time-space distances, making them greater then than they appear now, but even in Ferguson's time Logierait was within a few days travel by horse-drawn coach from Scotland's main Lowland centres. The wild Highlands of Jacobean lore - and the period of Ferguson's birth and upbringing were marked by the two uprisings - was much further north and west. The Statistical Analysis of Scotland 1791-99 survey at the end of the century (http://stat-acc-scot.edina.ac.uk/link/1791-99/ perth/logierait), the first of its kind, records the parish with a population of 2487 in 1755, the village itself had 200 in 1771. Six 'gentlemen' resided in the parish, along with shopkeepers, farmers, artisans and day labourers. The parish had 3000 acres in arable land and the survey said of the population: 'the general character of the people is sufficiently respectable. The virtues of humanity, frugality and industry, the best ornaments of human nature, flourish everywhere' (http://stat-acc-scot.edina.ac.uk/link/1791-99/perth/logierait/ 5/81). The area was Gaelic speaking, and place names reflect this, but the survey noted that English was 'pretty generally understood here'. Presbyterianism dominated. Perth first witnessed Knox's regales in support of Protestantism and The Statistical Analysis records that toward the end of the century the parish of Logierait had 1800 Presbyterians, 10 Catholics and 39 Episcopalians. The area was not ethnically Catholic-Gaelic, isolated and distant from the Lowland belt, and thus not truly 'rude' or 'barbarous' in terms of Ferguson's typology of social structures.

Nor is there evidence that Ferguson was ethnically Gaelic. Ferguson spoke Gaelic and initially ministered in a Highland regiment - established to suppress the Jacobean rebellion - but his father, while also a Gaelic speaker and called Adam, brought his son up strictly Presbyterian and anti-Jacobean. Moreover, Adam junior was educated in Perth grammar school rather than Logierait, and then at St Andrews, Scotland's oldest university, and Edinburgh, thoroughly Lowland in physical and cultural space. When young, Ferguson's father was befriended by Lord George Murray, son of the $2^{\text {nd }}$ Earl of Atholl (Fagg 1994: 290), took refuge with the Atholls at Blair Castle until the 1715 Jacobite uprising was quelled and pastored the family in later life; Adam junior grew up with aristocrats as playmates. Adam senior's first post was a tutor to 
the children of gentry, Sir Robert Laurie, and with the sponsorship of Earl Atholl moved into the Ministry in order to convert Gaelic speakers to Presbyterianism. Theologically at least he was anti-Catholic; his first homily was an exegesis on the papacy as the antichrist (Fagg 1994: 292), and while he was charitable to Catholics in not persecuting them in civil courts - for which he was criticized by his presbytery - he was vigorous in evangelizing them. He was a strong supporter of the Scottish Society for the Propagation of Christian Knowledge, whose mission was to convert the Highlands and to impose English instruction in schools (Fagg 1994: 297), being instrumental in establishing schools throughout the area with English-speaking schoolmasters. Logierait school, where Adam junior received his preliminary education, employed English as the language of instruction; and young Adam was brought up in a home where his father was proclaiming the edifying benefits of non-Gaelic speaking and complaining against 'the ignorance and barbarity that rages in this country' (quoted in Fagg 1994: 297). Indeed, Adam senior moved his family in 1714 - before Adam junior, his last son, was born - from the more isolated Braemar region of the Highlands to Logierait precisely because it was not isolated (Fagg 1994: 303). In the ' 45 rebellion his father was consulted by Colonel Yorke about the rebels and gave advice about whom to hang (Fagg 1994: 308). Clearly this was no bucolic, happy little crofter household; Ferguson's father had been Moderator of the Perth and Stirling Synod in 1728 and his mother was the sister of the $10^{\text {th }}$ Laird of Hallhead in Aberdeenshire and could trace her ancestry to the Dukes of Argyle.

None the less, the Highlands are a socially constructed space and to Lowlanders in Edinburgh in the mid-eighteenth century - fashionably calling itself at the time the Athens of the North - Logierait no doubt appeared barren and barbarous. Pitlochry, a few miles north up the Tay Valley, was about as far as Lowlanders went when 'doing the tour' of the Highlands in the eighteenth century; it was where Ferguson took Hume and other friends for a Highland excursion, an outing he records in one of his unpublished essays (Ferguson 1986: 23-53). Ferguson repeatedly draws on the mythology of the wild Highlander in reporting this excursion when referring to his friends as Lowlanders, beginning his recounting with the tale that he fired shots outside their window at four in the morning as a walk-up call. The place was thus part of an imagined space in order to draw differences between the Lowlands and the rest of Scotland.

Perceptions of Ferguson's life and work became wrapped up in this symbolism. Sir Walter Scott's anecdote of Ferguson abandoning the Bible for the claymore at the Battle of Fontenoy and having to be told by his colonel to desist from killing, only to have the broadsword tossed at him by an unwilling warrior shouting 'damn my commission', is enthusiastically reiterated as proof of Highland martial values. It is myth; the battle was fought months before he even enlisted. Commentators are here buying into the mythology surrounding the 
Highlands, reproducing the symbolic construction of space in Scottish society. None the less, it is repeated in serious sources (Sorenson 2002:110), and the bizarre, like 'The Gathering of the Clans' website, appropriately known as 'Tartans.com', which now has him leading the charge (it is ironic then that in one letter Ferguson should not refer to Scotland as a nation but as 'North Britain', see Merolle 1995a: 115). Despite his hamming of the Highland excursion, Ferguson mentions that he kept missing the deer and the essay is primarily used as a discourse against Epicurean notions of leisure; shooting animals seems a good idea to demonstrate the value of finding true happiness in activity but the man was too unskilled in country ways to bag any. Regardless, the myth remains: the uncouth, clannish Gaelic Highlander made the journey to liberal, commercial, cosmopolitan Edinburgh and wrote a book about it.

\section{The absent autobiographical narrative}

Try as commentators might to portray Ferguson as a wild Highlander, writing the Essay as a journey of selfhood, this does not correspond to the reality of Ferguson's upbringing or alluded to in his writings. Ferguson never mentions his Highland roots in the Essay and nowhere in the two volumes of his letters (published as Merolle 1995a and 1995b) does he engage in an autobiographical narrative to connect his life and work, let alone draw on a dramatization of his Highland and Gaelic roots to offer his own explanation of his intellectual biography or the genesis of the Essay. In a letter written in 1798 to Henry Mackenzie, editor of the Report of the Committee of the Highland Society investigating the authenticity of the famous poems of Ossian, Ferguson felt the need to qualify his evidence by establishing that his background and upbringing did not give him special authority.

As to my qualification to give evidence on this matter, the Committee will please to know that the place of my nativity in Athole is barely within the limits at which Gaelic begins to be vulgar tongue and where the mythology and tradition of the highland were likely to be more faint... It was a language spoken in the cottage but not in the parlour or at the table of gentlemen... It was connected with disaffection and proscribed by government. Schools were erected to supplant it . . the fashionable world in the neighbourhood derided the tone and accent of Highlanders (Merolle 1995b: 430-1).

It is hardly surprising therefore that in one of his letters Ferguson describes himself as a 'bastard Gaelic man' (Merolle 1995b: 353): a comment on his lack of Highland authenticity rather than parentage. In letters about the death of his beloved wife, his own impending death, or at family rites of passage he does not engage in personal reflexivity, identity construction or self-impression 
management. There is no 'epistolary self', as Liz Stanley (2004) describes the tendency to self-narration in letters. None of the memorials at the time of his death refer to the Highlands, nor do his own draft epitaphs (for details of which see Appendix O in Merolle 1995b).

There are biographical and sociological reasons for this. Ferguson had no biographical imperative to use his roots as a rationalization for the misfortunes of his intellectual career. Ferguson was not an outsider or occupational loner and did not have difficult relationships with colleagues and fellow writers, being on personally friendly terms with all rival doyens. Ferguson was firmly integrated into Edinburgh intellectual and cultural life, a member of several societies and clubs, being a founder of the famous Poker Club (on which see Fagg 1995: xxxv) and one of the original twelve in the Royal Society of Edinburgh; he consorted with aristocrats and 'gentlemen' and undertook tours of the Highlands mostly only to observe the agricultural improvements made by large landowners. His pamphleteering was perceived by politicians like Sir John Dalrymple as 'of real use to the government' (cited in Fagg 1995: xlix). The spaces in which Ferguson subsequently lived, worked and visited - he was a frequent intellectual and cultural tourist - thus could not have resonated negatively with his roots, so Logierait was not a social space either from which he felt the need to flee or a crucifix that he constantly carried as affliction. Ferguson had a cosmopolitan mentality: in one letter from Italy he referred to Edinburgh, after hearing its name, as o Dulcia Verba - oh sweet words (Merolle 1995a: 33). And while on retirement Ferguson initially farmed, he missed 'cordial' company and regretted that he could not afford to stay in Edinburgh. There was no disjuncture between his spaces of selfhood to shape the impact of his life on his work and no imperative to offer an autobiographical narrative to explain away, rationalize or otherwise construct his own preferred reading of the connection between his life and work.

It must also be stressed that eighteenth-century precursors of sociology did not engage in personal reflexivity about their social identity or construct preferred readings of their intellectual biographies because the 'self' was not recognized as an intellectual category within sociology as it existed before the discipline was named. What discussion there was amongst the Scots about individuals was conducted in terms of explicating the social consequences of either human nature in the abstract, as with Ferguson, who in one of his later letters described his 'trade', as 'the study of human nature', or of moral sentiments, as in Smith's early work. Thus they did not conceive their work as an engagement with the intersection between biography and the social structure, as so famously expressed in Mills's characterization of the sociological imagination (1959[2000]). It was the modernity project that dominated eighteenthcentury precursors of sociology - explicating the origins, nature and development of the newly emerging commercial and proto-industrial society. This was especially so in eighteenth-century Scotland because of its more rapid 
modernization compared to England and the rest of Europe, which is why its earlier proto-industrialization encouraged the most advanced proto-sociology, enabling it to be truly said to have anticipated some themes of nineteenthcentury sociology's critique of modernity.

The early stage of Scotland's modernisation is itself significant for explaining why biography never entered as an issue into the Scots' consideration of the newly emerging form of society. As Giddens (1991) and other contemporary sociologists have argued, biographical reflexivity and attention to issues of self and identity require more advanced forms of modernization. However, there is also something about Ferguson's biography as a Scotsman that accounts for this. He had an easy comfort in managing Logierait as a space of selfhood, giving no biographical imperative to explain how he turned personal experience into proto-sociology.

\section{Conclusion}

Ferguson's lack of reflection on his autobiographical self as it relates to his social thought is telling compared to the centrality of the self in later sociology. However, while the absence of an epistolary self in these early writers may not be unusual to sociologists aware of the history of their discipline, it remains incredible to philosophers who would likely counterpoise Giddens's argument with Augustine's The Confessions to claim reflection about the self to be an ancient quest. In an argument developed entirely independent of Giddens but thoroughly consistent with him, the philosopher Charles Taylor's monumental history of the self (1989) shows how modern notions of self, identity and self reflexivity do indeed emerge only very late in intellectual history. While Taylor's arguments are not universally popular amongst philosophers, they can be utilized to substantiate the claims here about the strengths and weaknesses of eighteenth-century proto-sociology.

Taylor argues that in antiquity the self was portrayed as a moral space, wherein people recognized themselves and others as moral beings deserving dignity. They were not therefore writing about 'identity' in the modern sense nor the 'social self', if we take this to mean people's awareness of their own activity in relation to a social world they share inter-subjectively with others, the cognitive processing of which involves constructing their own representation of their self as it is in relation to others. Such a conception requires not only an understanding of social bonds and relationships but also awareness that people place themselves as agents in relation to these bonds. Whilst the Greeks formulated the injunction 'know thyself', they did not use the term 'self' in their writings about social relations. The self was a moral but not yet a social notion. Plato for example, linked discourses about the self to the need to control human desire and in this state of calm to be in possession of oneself by 
mastery over passions and desires. This was taken to a spiritual plane with Augustine, whose arguments suggest a close alliteration between self, sin and the soul. Without a conception of social bonds and social relationships, Augustine's discourses about the self were linked to a person's relationship with the divine. The Greeks' injunction of 'know thyself' in order to control oneself, was transformed into know oneself in order to know God. Paradoxically, this is precisely the attitude adopted by the Protestant reformers centuries later: the self was a moral space to encounter God not society, although clearly, as Weber reminds us with respect to the Calvinists, all morality has social consequences.

As Taylor makes clear (1989: 143ff), the Enlightenment merely substituted reason for God, placing the moral source of the self within our reason as the means to control human nature. Descartes' The Passions of the Soul (1989 [1650]) urges on people the Platonic ideal of knowing one's self in order to 'conquer the passions'. The focus on reason initiated the secularization of the self as Enlightenment writers laid stress on the self as the source of selfknowledge that enabled the triumph of reason over passion. Montaigne, in Taylor's analysis (1989:178-84), appears to take a step nearer to the idea of the social self when he recognized that people bear the stamp of society (what he called 'the human condition') but ended the forward leap abruptly when arguing that the purpose of self knowledge was self acceptance: sanity not society was the purpose of self reflection.

Whilst compressing a great deal of nuanced argument and detailed intellectual exchange, it is none the less fair to claim that by the seventeenth and eighteenth centuries, intellectual discourses that were worlds apart converged in their understanding of the self as a moral rather than social space. The Augustinians and the Protestant reformation had inculcated a culture of introspection to equate the self with salvation, and Greek antiquity and the Enlightenment equated it with rational control over human desire. The self had still not emerged as a social entity, in which people turn inward to become aware of their own activity in relation to a social world they share intersubjectively with others, the cognitive processing of which involves constructing their own representation of their self in relation to others.

The advance made by the Scottish Enlightenment - but with deep debt to people like Shaftesbury some time before - was to begin to recognize the importance of the social bond, or sentiment as Smith put it, civil society as Ferguson named it. By the eighteenth century, sentiments restricted to the private domestic sphere like love, concern, affection, cherishment and empathy, become projected onto public space and society in general. The social bond was portrayed as being made up of the same solidarity of identification and affection as the family; sentiments animating our feelings toward those close to us were projected onto the generalized other. People's moral senses thus were recognized as predicated on a social bond. This realization offered the first opportunity for the self to become seen as a social entity as well as a moral one, and for 
self reflection to lead us outward to society as well as inward to salvation, sanity or self-control. This after all is the thrust of the arguments discussed earlier that Ferguson, amongst other Scots, was a proto-sociologist with a strong sense of the social structure as an interconnecting set of processes and institutions.

Why then did the self not emerge as a category to affect the sorts of reflections Ferguson made in his writings and which might have given a glimpse of his 'epistolary self'? Why is there no autobiographical narrative that engages in self reflection and discloses Ferguson's own sense of the connection between his life and work? Why did he completely neglect to mention his Highland connections? As we have argued, Ferguson had an easy satisfaction with his Scottish roots and no biographical need to confront an occupational or cultural marginality. Ferguson's Presbyterianism did not encourage him to contemplate the fates privately but urged him to activism, something reinforced by his affection for Stoicism and civic humanism, all of which culminated in his account of civil society. This commitment to action focused him on the travails of the modern commercial society then emerging in Scotland and raised his anxieties about its negative effects on the very social bonds that were beginning to be recognized as the source of our moral sense. This led him away from direct attention on the social self to the modernity project that threatened it. This was Ferguson's strength and his weakness, denuding his writings of an epistolary self but making him a perspicacious analyst of society and a significant forerunner of sociology.

(Date accepted: November 2006)

\section{Note}

1. This is a revised version of two papers. The first was presented to the $3^{\text {rd }}$ International Reid Symposium on Scottish Philosophy, Centre for the Study of Scottish Philosophy, University of Aberdeen, 12-14
July 2004, the second to the Scottish Philosophy Network, Centre for the Study of Scottish Philosophy, University of Aberdeen, 27 November 2004.

\section{Bibliography}

Allan, D. 2006 Adam Ferguson, Edinburgh: Edinburgh University Press.

Barnes, H. 1917 'Sociology Before Comte', American Journal of Sociology 23: 174-247. Benton, T. 1978 'How Many Sociologies?' The Sociological Review 26: 217-36.

Benton, T. 1992 'Adam Ferguson's Critique of the 'Enterprise Culture', in P. Heelas and P. Morris (eds) The Values of the Enterprise Culture, London: Routledge.
Brewer, A. 1999 'Adam Ferguson, Adam Smith and the Concept of Economic Growth', History of Political Economy 31: 237-55.

Brewer, J.D. 1986 'Adam Ferguson and the Theme of Exploitation', The British Journal of Sociology 37: 461-78.

Brewer, J.D. 1987 'The Scottish Enlightenment', in A. Reeves (ed.) Modern Theories of Exploitation, London: Sage. 
Brewer, J.D. 1989 'Conjectural History, Sociology and Social Change in Eighteenthcentury Scotland: Adam Ferguson and the Division of Labour', in D. McCrone, S. Kendrick and P. Straw (eds) The Making of Scotland, Edinburgh: Edinburgh University Press.

Bryson, G. 1939 'Some Eighteenth Century Conceptions of Society', The Sociological Review 31: 401-21.

Bryson, G. 1945 Man and Society, Princeton: Princeton University Press.

Bullough, V. 1970 'Intellectual Achievement in Eighteenth-century Scotland', Comparative Education Review 14: 90-102.

Bullough, V. and Bullough, B. 1971 'Intellectual Achievers: A Study of Eighteenthcentury Scotland', American Journal of Sociology 76: 1048-63.

Christie, J. 1974 'The Origins and Development of the Scottish Scientific Community 1680-1760', History of Science 12: 122-41.

Dahrendorf, R. 2002 'Adam Ferguson: How Civil Will Future Society Be?' http://www. ed.ac.uk/events/lectures/enlightenment.

Descartes, R. 1989[1650] The Passions of the Soul, transl. Stephen Voss, Indianapolis, Indiana: Hackett Publishing Company.

Edwards, M. 2004 Civil Society, Cambridge: Polity Press.

Emerson, R. 1973a 'The Enlightenment and Social Structure', in P. Fritz and D. Williams (eds) City and Society in the 18th Century, Toronto: Hakkert.

Emerson, R. 1973b 'The Social Composition of Enlightened Scotland: The Select Society of Edinburgh 1754-1764', Studies on Voltaire and the Eighteenth Century 114: 291-329.

Fagg, J. 1994 “ "Complaints and Clamours": The Ministry of Adam Fergusson 17001754', Records of the Scottish Church History Society 25: 288-308.

Fagg, J. 1995 'Biographical Introduction', in V. Merolle 1995a The Correspondence of Adam Ferguson, Vol. 1, 1765-1780, London: William Pickering.

Ferguson, A. 1966 [1767] An Essay on the History of Civil Society, Edinburgh: Edinburgh University Press.
Ferguson, A. 1986 'An Excursion in the Highlands', in W. Philip (ed.) The Unpublished Essays of Adam Ferguson Vol. 3, Kilberry: Argyll.

Forbes, D. 1966 'Introduction', in A. Ferguson An Essay on the History of Civil Society, Edinburgh: Edinburgh University Press.

Forbes, D. 1967 'Adam Ferguson and the Idea of Community', in D. Young (ed.) Edinburgh in the Age of Reason, Edinburgh: Edinburgh University Press.

Force, J. 1984 'Hume and the Relation of Science to Religion Among Certain Members of the Royal Society', Journal of the History of Ideas 55: 517-53.

Gellner, E. 1994 'Adam Ferguson', in E. Gellner Conditions of Liberty, London: Hamish Hamilton.

Gellner, E. 1996 'Adam Ferguson and the Surprising Robustness of Civil Society', in E. Gellner and C. Cansino (eds) Liberalism in Modern Times, Budapest: Central European University Press.

Giddens, A. 1991 Modernity Self-Identity Self and Society in the Late Modern Age, Cambridge: Polity Press.

Hill, L. 1996a 'Ferguson and Smith on "Human Nature", "Interest" and the Role of Beneficence in Market Society', History of Economic Ideas 4: 353-99.

Hill, L. 1996b 'Anticipations of Nineteenth and Twentieth Century Social Thought in the Work of Adam Ferguson', Archives Europeennes de Sociologie 37: 203-28.

Hill, L. 1997 'Adam Ferguson and the Paradox of Progress and Decline', History of Political Thought 18: 677-706.

Hill, L. 1998 'The Invisible Hand of Adam Ferguson', The European Legacy 3: 42-64.

Hill, L. 2001a 'Eighteenth-century Anticipations of the Sociology of Conflict: The Case of Adam Ferguson', Journal of the History of Ideas 62: 281-99.

Hill, L. 2001b 'The Hidden Theology of Adam Smith', European Journal of the History of Economic Thought 8: 1-29.

Hont, I. and Ignatieff, M. 1983 Wealth and Virtue, Cambridge: Cambridge University Press. 
Hopfl, H. 1978 'From Savage to Scotsman: Conjectural History in the Scottish Enlightenment', Journal of British Studies 17: 1940.

Kalyvas, A. and Katznelson, I. 1998 'Adam Ferguson Returns: Liberalism Through a Glass Darkly', Political Theory 26: 173-97.

Keane, J. 1988 'Democracy and Despotism', in J. Keane (ed.) Civil Society and the State, London: Verso.

Kettler, D. 1965 The Social and Political Thought of Adam Ferguson, Ohio: Ohio State University Press.

Kettler, D. 1977 'History and Theory in Ferguson's Essay on the History of Civil Society: A Reconsideration', Political Theory 5: 437-60.

Kugler, M. 1996 'Provincial Intellectuals: Identity, Patriotism and Enlightened Peripheries', The Eighteenth Century 37: 156-73.

Lehmann, W.C. 1930 Adam Ferguson and the Beginnings of Modern Sociology. New York: Columbia University Press.

Livingstone, D. 2004 'Public Spectacle and Scientific Theory: William Robertson Smith and the Reading of Evolution in Victorian Scotland', Studies in the History and Philosophy of Biological and Biomedical Sciences 35: 1-29.

MacIntyre, A. 1985 After Virtue, London: Duckworth.

MacRae, D. 1969 'Adam Ferguson', in T. Raison (ed.) The Founding Fathers of Social Science, London: Penguin.

Mason, S. 1988 'Ferguson and Montesquieu: Tacit Reproaches', British Journal for Eighteenth-Century Studies 11: 193-203.

Meek, R. 1967 'The Scottish Contribution to Marxist Sociology', in R. Meek Economics and Ideology, London: Chapman and Hall.

Merolle, V. 1995a The Correspondence of Adam Ferguson, Vol. 1, 1745-1780, London: William Pickering.

Merolle, V. 1995b The Correspondence of Adam Ferguson, Vol. 2, 1781-1816, London: William Pickering.

Mills, C.W. 1959 [2000] The Sociological Imagination, Now York: Oxford University Press.
Morrell, J. 1970 'The University of Edinburgh in the Late Eighteenth-century: Its Scientific Eminence and Academic Structure', Isis 116: 158-71.

Oz-Salzberger, F. 1995 Translating the Enlightenment, Oxford: Clarendon Press.

Pascal, R. 1938 'Property and Society: The Scottish Historical School of the Eighteenth Century', Modern Quarterly 1(2): 167-79.

Passey, A. and Tonkiss, F. 2000 'Trust, Voluntary Association and Civil Society', in F. Tonkiss and A. Passey (eds) Trust and Civil Society, London: Macmillan.

Pocock, J. 1985 Virtue, Commerce and History, Cambridge: Cambridge University Press.

Robertson, J. 1985 The Scottish Enlightenment and the Militia Issue, Edinburgh: Donald.

Seligman, A. 2000 'Trust and Civil Society', in F. Tonkiss and A. Passey (eds) Trust and Civil Society, London: Macmillan.

Shapin, S. 1974 'The Audience For Science in Eighteenth-century Edinburgh', History of Science 12: 95-121.

Sher, R. 1985 Church and University in the Scottish Enlightenment, Princeton: Princeton University Press.

Sher, R. 1989 'Adam Ferguson, Adam Smith and the Problem of National Defense', Journal of Modern History 61: 240-68.

Sher, R. 1990 'Professors of Virtue: The Social History of the Edinburgh Moral Philosophy Chair in the Eighteenth Century', in M. Stewart (ed.) Studies in the Philosophy of the Scottish Enlightenment, Oxford: The Clarendon Press.

Skinner, A. 1982 ‘A Scottish Contribution to Marxist Sociology?', in I. Bradley and M. Howard (eds) Classical and Marxian Political Economy, London: Macmillan.

Sorenson, R. 2002 'Fame as the Forgotten Philosopher: Meditations on the Headstone of Adam Ferguson', Philosophy 77: 10914.

Stanley, L. 2004 'The Epistolarium: On Theorizing Letters and Correspondences', Auto/Biography 12: 201-35. 
Swingewood, A. 1970 'Origins of Sociology: Tonkiss, F. 1998 'Civil-political', in C. Jenks The Case of the Scottish Enlightenment', (ed.) Core Sociological Dichotomies, The British Journal of Sociology 21: 164-80. London: Sage.

Taylor, C. 1989 Sources of the Self, Cambridge: Harvard University Press. 